\title{
ALTMAN Z-SCORE MODEL FOR BANKRUPTCY FORECASTING OF THE LISTED LITHUANIAN AGRICULTURAL COMPANIES
}

\author{
Vaiva Kiaupaite-Grushniene \\ Tallinn University of Technology
}

\begin{abstract}
Since development in 1968, Altman's Z-score has been widely used to judge the risk of financial failure by companies in various countries, industries, and time-periods. The purpose of this paper is to apply Altman's Z-score model for bankruptcy prediction on the three listed Lithuanian agricultural companies. Agribusiness is an important industry in Lithuania and recent trends of consolidation and long-term government subsidies make evaluation of financial health of such companies important not only for the owners, but for the other stakeholders as well. The study has found that the model correctly places companies into "safe" and "grey" zones, which gives initial information for the stakeholders. Further exploratory study into the financial and non-financial factors constituting Z-score could provide additional information for forecasting firm's performance.
\end{abstract}

Keywords: Corporate bankruptcy, Prediction models, statistical prediction models; organizational theory

JEL code: G33, G170, Q130

\section{Introduction}

Numerous researchers have studied bankruptcy prediction for the past century. Financial stress has been analysed from the economic, financial, accounting, statistical, organizational and informational point of view. Many academic studies have been dedicated to finding the best corporate failure prediction model, both in developed and developing countries. As a result, the literature body is quite extensive. The main factors for such development are that corporate performance has become one of the most investigated topics in finance and strategic literature, and the increased availability of credible financial data, coupled with development of statistical techniques and informatics (Dimitras et al., 1996). Dimitras notes that past and current studies in business failure prediction are generally conducted because of inductive reasoning with little or no reference to the theoretical framework (Dimitras et al., 1996). This trend explains why business failure literature is highly fragmented, as researchers choose to study some particular aspects or stages of business failure process according to their experience or interests, and the results are inferred from the analysis of empirical data collected on specific samples (Morris, 1997).

Chronologically, financial failure research could be divided into two parts: before and after 1990s. The techniques of bankruptcy prediction prior to 1990 s were dominated by static single-period classification models, which attempted to find unique characteristics that differentiate between successful and failed companies. Starting with P. J. FitzPatrick (1932), who is considered the first researcher to use univariate analysis in a comparison of ratios of successful and failed industrial companies (Levins, 1997). Later research by Beaver (1968) and Altman (1968) further considered the ability of combination of financial ratios to predict bankruptcy.

In 1990s, the techniques focused more on dynamic models, which would determine a company's distress risk at each point in time (Shumway, 2001). It has led to a flow of "new techniques", discussed in detail in Cybinski (2003), Altman, and Hotchkiss (2005), which focus mainly on quantitative techniques. According to Dimitras et al. (1996) this trend is 
rather worrying, as most of these studies focus on ability of quantitative techniques to correctly predict business failure one to five years prior to legal bankruptcy, considering that managers were unaware of the problems their companies face and were unable to take corrective actions. Almost no research appears to focus on the bankruptcy prevention aspects in prediction modelling, despite the economic significance of the latter.

The process to discriminate between bankrupt and on-business companies began with Beaver in 1966 and was popularized by Altman's (1968) Z-score based on multiple discriminant analysis (MDA). These models have served as a basis for variety applications, including portfolio selection, credit evaluation, and turnaround management (Dietrich et al., 2005).

Although there have been criticisms of the effectiveness of MDA models (Agarwal and Tafler, 2005, 2006), currently the usefulness of ratio analysis is reiterated, showing the power of financial ratios to explain the main processes of value creation activities in the firm as well as failure risk prediction. Altman, Iwanich-Drozdowska, Laitinen and Suvas (2014) have prepared an in-depth literature review of Z-score application over 31 countries, which concluded that original Z-Score works "reasonably well" in international context, especially if it is used as risk measure tool.

This study makes contributions to literature by focusing on a rather specific industry agriculture, and attempts to evaluate applicability of Altman's Z-Score model on publicly traded agricultural enterprises in Lithuania.

Agribusiness represents a link in connecting farmers with retailers and consumers, yet little research has been done to examine historical performance of food processing firms. In recent decades, agricultural sectors of Europe have witnessed two tendencies: long-term upward tendency of input prices and long-term downward tendency for output prices (Vavrina et al., 2013). Financial health evaluation of agricultural enterprises is a topic of special importance not only from investor, but also from government and owner point of view. After accession to EU, Lithuanian farmers are receiving significant subsidies from both EU and National Budget, and those subsidies are intended to be provided only to financially heathy enterprises with future perspectives of their sustainable economic performance. Therefore, there is a need to know how to distinguish the well performing enterprises from those likely to face financial problems. Vertical integration and consolidation of agribusiness, also place additional pressure on the skill level of agricultural management.

The paper is structured as follows. The following section will provide a short overview of literature followed by an overview of Lithuanian agricultural sector. Next sections outline the methodology used, results obtained and analysis of results, while final conclusions are drawn in the last section.

\section{Literature Review}

Financial distress is a state of failing to meet financial obligations to creditors. There are many events which may lead a company into the difficult financial position, such as continuous heavy fixed costs, less liquid assets, revenue and sensitivity to economic cycles, etc. The costs of financial distress are typically classified as either direct or indirect: direct being costs of advising during restructuring, legal fees, accounting fees, etc. and indirect being costs arising due to shift of management focus from running the business to saving the life of it (Warner, 1977). Many researchers state that failure is not a sudden event, but rather a process, when before reaching ultimate failure of declaring bankruptcy, company goes through various phases. This view signifies importance of early warning signs detection, which allows management to take corrective action and avoid failure. 
Altman and Hochkiss (2006) described four basic terms of bankruptcy, default, insolvency and failure which are used differently by various researchers. Technical insolvency is a situation in which a company is unable to fulfil its current obligations due to liquidity. Whereas bankruptcy itself is a formal declaration of bankruptcy by court as a result of a petition for bankruptcy reorganization or liquidation of assets.

Factors of failure are varied in agricultural sector, with main ones being similar to other firms, such as heavy debt levels, high interest rates, declining profits due to recession and/or adverse environmental effects (droughts, floods, frost).

Following Beaver (1966) and Altman's (1968) seminal work, numerous studies suggest that corporate failure can be theoretically explained and empirically tested. The literature on methodological issues associated with corporate failure prediction models has been well documented in a number of reviews. These include Scott (1980), Zmijevski (1984), Taffler (1984), Altman (1984), O'Leary (1998), Keasey and Watson (1991), Altman and Narayanan (1996), Dimitras el al (1996), Moris (1997), Aziz and Dar (2002, 2006), Balcaen and Ooghe (2006). A number of question has been raised, and in particular there has been a concern with the reliability and accuracy of accounting information provided by the organizations in their annual reports.

Accounting-based models test the usefulness of information contained in the financial statements to provide adequate assessment of firm's financial distress risk. These techniques are based on a single ratio, or a number of ratios which are computed and compared to a benchmark, in order to allocate a firm to one of the two groups: successful or financiallydistressed. Since the distress in traditional accounting models is measured by dichotomous variable which classifies a company as successful or financially distressed with respect to a specific cut-off, these models are known as binary or dichotomous models. Financial data used in accounting-based models is ex-post, such as profitability, liquidity, solvency ratios.

The relative simplicity and availability of financial information have made these techniques the most popular tools for decades. Agarwal and Taffler (2006) compared performance of two models and have concluded that there was little difference in predictive accuracy of market-based and accounting-based models.

Bankruptcy prediction specifically for the sector of agriculture, has been investigated by several researchers as well. Turvey et al (2000) used a combination of financial performance measures (ROA, ROE, share prices) to examine listed North American food processing firms and found limited support for the thesis that high economic value added firms create wealth for shareholders. Robelo (2012) has evaluated the risk of insolvency for Portuguese agricultural credit cooperatives, and identified the main determinants of failure: customer base growth, transformation ratio, credit overdue, expenses ratio, structural costs, liquidity, indebtedness, and financial margin.

Katchova and Enlow (2013) explored historical financial performance of publicly traded US agribusinesses and revealed that agribusinesses outperform that median sample of firms in terms of profitability, liquidity, operating efficiency and market ratios, but show lower liquidity and debt ratios.

Lukason (2014) has investigated failure process and causes in the Estonian agricultural sector. The author concluded that agricultural firms go through a unique failure process as compared to other sectors, with reasons for failure being internal and external with the same frequency.

Lithuanian agricultural sector has been analysed by Slavickiene and Savieckiene (2014). The authors have evaluated methodology of farm economic viability assessment and applied it on a sample of private farms in Mariampole district. Stulpinine (2011) has developed a 
theoretical framework for measurement of farm financial distress with a combination of variables for: immediate environment, general environment, management, farm policy, and farm characteristics.

Altman's Z-Score model has been successfully applied in by Jakovcevic and Adrasic (2012) on a sample of Serbian agricultural-industrial companies, by Popescu (2014) on a sample of Romanian dairy firms.

\section{Altman Z-Score model}

In 1968 Altman has applied multivariate discriminant analysis to derive a linear combination of ratios, which "best" discriminate between financially distressed and non-distressed firms. He has used a matched-pair sample of 33 bankrupt and 33 non-distressed companies from the same industry. Similar to Beaver, 22 ratios for analysis were selected based on their popularity in literature and potential relevance for study. These were grouped into five categories: profitability, liquidity, leverage, solvency and activity. After statistical analysis, Altman has identified 5 most important ratios and proposed the following discriminant function, known as “Altman's Z-Score”:

\section{$\mathrm{Z}=1.2 \mathrm{X}_{1}+1.4 \mathrm{X}_{2}+3.3 \mathrm{X}_{3}+0.6 \mathrm{X}_{4}+.999 \mathrm{X}_{5}$}

where $\mathrm{X}_{1}=$ Working capital/Total assets, $\mathrm{X}_{2}=$ Retained earnings $/$ Total assets, $\mathrm{X}_{3}=$ Earnings before interest and taxes/Total assets, $\mathrm{X}_{4}=$ Market value equity/Book value of total debt, $\mathrm{X}_{5}=$ Sales/Total assets, $Z=$ Overall Index (Altman, 1968).

Firms having Z-Score higher than the cut-off are classified as financially sound, while the ones with lower Z-score as having a higher probability of default. The model had Type I error of $6 \%$ and Type II error of 5\% respectively, thus was more accurate than Beaver's model.

In 1990s, Altman has revisited his Z-score and analysed the changes, which contributed to the overall increase in business risk (Altman and Narayan, 1997). Altman also came with Z-Score for the private companies, with adjusted coefficient weights and $\mathrm{X}_{4}$ coefficient is determined as the ratio between the book value of companies own and borrowed capital (debt) (Altman and Hochkiss, 2006)

\section{$\mathrm{Z}=0.717 \mathrm{X}_{1}+0.847 \mathrm{X}_{2}+3.107 \mathrm{X}_{3}+0.420 \mathrm{X}_{4}+0.998 \mathrm{X}_{5}$}

Although there has been much criticism regarding the effectiveness of Z-score models, currently the usefulness of ratio analysis is reiterated (Agarwal and Taffler, 2005). Despite application of more complicated computational techniques, bankruptcy prediction models have not significantly improved. Therefore, Z-score model continues to be used in a variety of business situation from actual bankruptcy to other financial distress conditions. Commercial banks us the model as part of the periodic loan review process, investment bankers use the model in security and portfolio analysis, it has been applied as management decision tool and as an analysis tool by auditors to assess clients' ability to continue as going concern (Grice and Ingram, 2001).

\section{General overview of agricultural sector}

Agribusiness is defined as economic activity of the farm or firms that assemble, process and transform raw agricultural commodities into final products for distribution. Agribusiness also includes all economic activities that support farm production and conversion of raw materials, such as machinery repairs, fertilizer production, farming itself, food processing and manufacturing, transportation, wholesale and retail trade (Katchova and Enlow, 2013). 
As in all Central and East European countries, Lithuanian's agricultural sector has historically been an important sector of the national economy. Land reform of 1922 provided 65,000 peasants with agricultural land. Of the 6.5 million hectares of land, the total agricultural area equalled 3.151 million hectares. Arable land accounted for 2.866 million ha, followed by meadows and natural pastures (0.441 million ha) and permanent crops (44,300 ha). With three-quarters of labor force employed in agriculture, Lithuania was a predominantly agricultural economy in 1940.

During Soviet times, agriculture has been collectivized and productivity has decreased significantly.

Land restitution and privatization of State Collective Farms was initiated in 1991 and encouraged the development of family farms. As of mid-1997, the restitution process has only resulted in ownership of less than $50 \%$ of agricultural land. Privatization also had a significant influence on development of the land market, as only registered land could be sold. Such restitution process resulted in "plotter" restitution, with owners having 2-3 ha lots and ineffective production. By mid-1990s, Lithuania has reached only one-fourth of the US labor productivity.

According to Agricultural census in Lithuania, during 2003-2010 timeframe, one third of agricultural holdings closed, with number of farms decreasing from 272,110 to 199,910 . On the other hand, the utilized agricultural land has increased 10\%, from 2,490,960 ha in 2003 to $2,742,560$ in 2010. Similarly, the average area per farm has increased from 9.2 ha in 2003 to 13.7 ha in 2010, which indicates that land consolidation in taking place. It follows global agribusiness structural change, of crop production shifting to larger operations, due to changes in technology and factor prices (Roberts and Key, 2008). According to 2010 data for Lithuania, majority of the land was owned by farmers who actually worked on the land: $1,406,610$ ha $(51.3 \%)$, while $1,273,390(46.4 \%)$, was cultivated by tenants.

In terms of economic output, Lithuanian agricultural holdings produced for EUR 1,526 million in 2010, which was by far highest in the Baltic States. The highest increase in output has been recorded in farms with an economic size ranging from 100,000 EUR to 249,499 EUR.

According to Eurostat report (2014), the share of Gross Domestic Product (GDP) generated in agricultural sector decreased from $4 \%$ in 2004 to $2.3 \%$ in 2009 and returned to $3.2 \%$ in 2011 (as compared to average $1.5 \%$ for 27 European Union Member States). The share of employees working in agricultural sector has been $15 \%$ in 2005 , and subsequently has decreased to $8.3 \%$ in 2008 and further down to $7.7 \%$ in 2011 (as compared to $4.9 \%$ for EU27). Thus, agricultural sector still plays a more important role in Lithuanian economy as compared to other EU states.

As noted above, collectivization and de-collectivization has rendered significant distortions in Lithuanian agricultural market. Another significant factor in sector development was Lithuania's European Union integration process, when after becoming EU member in 2004, Lithuania had to adjust its agricultural policies in line with Common Agricultural Policy (CAP). EU accession caused changes in external farming conditions, such as government support and taxation environment.

Agribusiness traditionally operates under several different business models, cooperatives being the most popular. Publicly-traded agribusinesses are defined as those that are publicly listed. Such firms have greater access to financing, because they can issue more stock, but are also subject to more regulation (Katchova and Enlow, 2013). Literature review shows, that such firms operate similarly to other public firms, thus allowing to apply Altman's model. 
In Lithuania, farm structure has been changing, in terms of both land area and farming types, consolidation taking place. This signifies importance in measuring efficiency of Lithuanian farms. With farms getting bigger and attracting financing from both financial institutions and European Union support, their failure would have an effect on larger group of stakeholders: shareholders, management, workers, lenders, supplies, clients, community and government. Also, financial failure and trouble forecast allows taking strategic corrective actions by management to prevent distress.

\section{Research methodology}

This study has applied multivariate discriminant analysis model (Altman's Z-score) in evaluating financial distress likelihood in a publicly traded agricultural organization.

\section{Data collection}

Research population consisted of three companies from 2010 till 2015. Sample size is limited by the fact that only three listed companies are available, with an object of their activity as crop production and livestock farming, agricultural land lease. This time period was considered long enough to provide sufficient variable analysis to assist in determining a trend. Also, it covers the time companies have been listed.

Data was sourced from secondary sources: aggregate financial statements of companies (Balance Sheet and Income (Loss) Statement). The companies chosen were agricultural holdings listed on Nasdaq Baltic Stock Exchange both Baltic Main List (Linas Agro) and Baltic Secondary List (Agrowill, Invalda Baltic Farmland). The database provides the financial statements, ratio analysis and product profile information.

Data has been analysed using Microsoft Excel program.

\section{Profiles of the companies}

\section{Linas Agro}

Linas Agro in an agricultural and food industry holding, established in 1991. It has started it operations with oilseed rape export to Western Europe. Currently company controls 34 subsidiaries in Lithuania, Latvia, Estonia and Denmark, has 2,250 employees, and as of 2010 has been listed in Nasdaq Vilnius Stock Exchange. The core produce of the company are grain, oilseed, raw feedstuffs, milk, poultry and its products. Linas Agro is one of the largest exporters of Lithuanian grain, a major milk producer in Lithuania and the largest poultry producer in Latvia.

Company also has seed processing plant and is one of the leaders in supplying production to farmers - certified seeds, fertilizers, plant protection products, and agricultural machinery. The group has seven agricultural companies located in fertile regions (Panevezys district Aukstadvario ZUB, Zibartorniu ZUB; Kedainiai district - Labunavos ZUB; Sakiai district Luksiu ZUB, Birzai district - Medeikiu ZUB, Uzupes ZUB and Sidabravo ZUB).

\section{Agrowill}

Agrowill has started operations in 2003, with establishment of "Agrovaldymo Grupe" and continued its growth with purchases of operating agricultural cooperatives in 2005 and 2006 (14 in total). Currently, Agrowill managers 30,000 ha of own and leased land property. The company's activities include cultural mushroom growing and sale, milk production and sale, grain, rape-seed growth and sale and rent of land. In 2009 the company has started restructuring procedure, in order to avoid bankruptcy. 


\section{Invalda Baltic Farm Land}

The company has been established in April 2014, as part of assets split-off from company "Invalda AB". It managers shares of companies investing into agricultural land, and currently has ownership of more than 3,000 hectares of land. The main activity of the company is rent of agricultural land to farmers and agricultural companies.

\section{Results and Discussion}

For the purpose of this study, Multivariate Discriminant Analysis (MDA) statistical technique used by Altman (1968) was applied. Since the scope of this paper is analysis of three public agricultural firms, original Altman's Z-Score has been used:

\section{$Z=1.2 X_{1}+1.4 X_{2}+3.3 X_{3}+0.6 X_{4}+.999 X_{5}$,}

where $\mathrm{X}_{1}=$ Working capital/Total assets, $\mathrm{X}_{2}=$ Retained earnings $/$ Total assets, $\mathrm{X}_{3}=$ Earnings before interest and taxes/Total assets, $\mathrm{X}_{4}=$ Market value equity/Book value of total debt, $\mathrm{X}_{5}=$ Sales/Total assets, $Z=$ Overall Index (Altman, 1968).

$\mathrm{Z}$ above 2.99 - safe zone, $1.81 \leq \mathrm{Z} \leq 2.99$ - grey zone, $\mathrm{Z} \leq 1.81$ - distress zone

Table 1 shows the determined Z-score values for each observed company year by year.

Table 1. Z-Scores for agricultural companies

\begin{tabular}{|l|c|c|c|c|c|c|}
\hline \multirow{2}{*}{ Company } & \multicolumn{7}{|c|}{ Years } \\
\cline { 2 - 7 } & $\mathbf{2 0 1 0}$ & $\mathbf{2 0 1 1}$ & $\mathbf{2 0 1 2}$ & $\mathbf{2 0 1 3}$ & $\mathbf{2 0 1 4}$ & $\mathbf{2 0 1 5}$ \\
\hline Linas Agro & 4.40 & 5.76 & 7.14 & 5.09 & 4.94 & 4.76 \\
\hline Agrowill & 0.20 & 0.19 & 0.47 & 1.19 & 1.23 & 1.58 \\
\hline Baltic Farm Land & & & & & 8.26 & 6.56 \\
\hline
\end{tabular}

As can be seen from the table, according to Altman's classification, Linas Agro and Baltic Farm Land are in safe zone, while Agrowill was in distress zone till 2012 and has moved to grey zone afterwards.

Z-Score breakdown for each company could give useful insights by itself.

Table 2. $\mathrm{X}_{1}=$ Working capital/Total assets scores for agricultural companies

\begin{tabular}{|l|c|c|c|c|c|c|}
\hline \multirow{2}{*}{ Company, $\mathrm{X}_{1}$} & \multicolumn{7}{|c|}{ Years } \\
\cline { 2 - 7 } & $\mathbf{2 0 1 0}$ & $\mathbf{2 0 1 1}$ & $\mathbf{2 0 1 2}$ & $\mathbf{2 0 1 3}$ & $\mathbf{2 0 1 4}$ & $\mathbf{2 0 1 5}$ \\
\hline Linas Agro & 0.21 & 0.33 & 0.30 & 0.24 & 0.23 & 0.20 \\
\hline Agrowill & 0.03 & $(0.06)$ & $(0.15)$ & $(0.02)$ & $(0.02)$ & 0 \\
\hline Baltic Farm Land & & & & & 0.02 & 0.02 \\
\hline
\end{tabular}

Working capital is the difference between current assets and current liabilities. $\mathrm{X}_{1}$ ratio considers the liquidity situation and the size of the company. Altman states that this ratio is the most significant one in this class, others being quick and current ratio. This ratio contracts if company is in a loss because its nominator decreases due to shrinkage of current assets. A company with negative working capital is very likely to have problems with payments.

Linas Agro has a positive ratio, but it has a decreasing trend. While in 2011 and 2012, current assets have increased more than current liabilities, from 2013 company's liabilities are 
increasing at a faster rate $(27 \%$ in $2013,3 \%$ in 2014 and $10 \%$ in 2015) than current assets (18\% in 2013, 1\% in 2014 and 3\% in 2015), which is not positive.

Agrowill company's data reflects situation after company has started restructuring in 2009 in order to avoid bankruptcy, which was caused by too fast expansion and inability to refinance short-term debt. From 2012, Agrowill's ratio even though is still negative, shows positive trend, as current assets are increasing at a higher rate (301\% in 2014 and $12 \%$ in 2015) than increase in current liabilities (279\% and $3 \%$ correspondingly).

Baltic Farm Land has a positive ratio, but more detailed analysis shows that current assets have increased by $83 \%$, while current liabilities by $366 \%$.

Table 3. $\mathrm{X}_{2}=$ Retained earnings/Total assets scores for agricultural companies

\begin{tabular}{|l|c|c|c|c|c|c|}
\hline \multirow{2}{*}{ Company, $\mathrm{X}_{2}$} & \multicolumn{7}{|c|}{ Years } \\
\cline { 2 - 7 } & 2010 & 2011 & 2012 & 2013 & 2014 & 2015 \\
\hline Linas Agro & 0.04 & 0.15 & 0.23 & 0.25 & 0.27 & 0.27 \\
\hline Agrowill & $(0.14)$ & $(0.15)$ & $(0.11)$ & $(0.04)$ & 0.10 & 0.12 \\
\hline Baltic Farm Land & & & & & 0.41 & 0.43 \\
\hline
\end{tabular}

$\mathrm{X}_{2}$ ratio represents accumulated earning of the company reinvested in the business. It measures cumulative profitability of the business and indirectly considers the age of the firm. Consequently, this ratio can be smaller for a young firm, which did not have time to accumulate profits yet. Therefore, it could be said that younger firms could be discriminated in this analysis and chances of failure rated as higher; on the other hand, it is a reality that young firms tend to fail more often. Accumulated earnings show company's monetary solidness. Another reason for this ratio is that high retained earnings show history of profits and ability of the company to face periods of losses. This ratio is also rather prone to "manipulation" via corporate quasi-reorganizations and stock dividend declarations (Altman, 1997) and also measures firm's leverage, as companies with high Retained Earnings/Total Assets ratio have financed their assets via profits and have not utilized much debt.

Linas Agro seems to be financing its assets with earnings, as $\mathrm{X}_{2}$ ratio remains constant.

Agrowill has had negative retained earnings up to year 2014, and assets growth has been financed with long term loans. Only in 2015, assets have grown $9 \%$ as compared to $32 \%$ increase in retained earnings.

Table 4. $X_{3}=$ Earnings before interest and taxes/Total assets scores for agricultural companies

\begin{tabular}{|l|c|c|c|c|c|c|}
\hline \multirow{2}{*}{ Company, $\mathrm{X}_{3}$} & \multicolumn{7}{|c|}{ Years } \\
\cline { 2 - 7 } & 2010 & 2011 & 2012 & 2013 & 2014 & 2015 \\
\hline Linas Agro & -- & 0.18 & 0.15 & 0.11 & 0.07 & 0.05 \\
\hline Agrowill & 0.04 & 0.04 & 0.05 & 0.09 & 0.10 & 0.06 \\
\hline Baltic Farm Land & & & & & 0.32 & 0.08 \\
\hline
\end{tabular}

$\mathrm{X}_{3}$ ratio is the measure of productivity of company's assets. It shows earning power of the assets which is a very important factor for existence of the company and is, therefore, a very important ratio for evaluation of credit risk of the company. Insolvency of the company occurs when total liabilities exceed fair value of the assets, with value determined by earning power of assets. 
Linas Agro has a positive ratio, however again with a decreasing trend. The decrease has been caused by year-to-year decrease in company's earnings (-6\% in 2013, $-37 \%$ in 2014 and $-19 \%$ in 2015).

Agrowill's ratio is lower, but has been experiencing positive trend till 2014. Both company's earnings and assets have been fluctuating on a year-to-year basis, thus clear reason for ratio change cannot be stated. 2012 improvement was due increased profitability, while 2013 improvement is a result of steeper drop in assets $(-53 \%)$ as compared to profitability drop (17\%). Year 2014 has shown a 274\% increase in profitability, which needs to be investigated whether it has been actual result or a result of accounting transaction.

Baltic Farm Land's ratio has declined due to steep drop in earnings (-71\% from 2014 to 2015).

In year 2015 all three companies have experienced decline of profitability, which could have been caused by decrease in production prices.

Table 5. $X_{4}=$ Market value equity/Book value of total debt scores for agricultural companies

\begin{tabular}{|l|c|c|c|c|c|c|}
\hline \multirow{2}{*}{ Company, $\mathrm{X}_{4}$} & \multicolumn{7}{|c|}{ Years } \\
\cline { 2 - 7 } & 2010 & 2011 & 2012 & 2013 & 2014 & 2015 \\
\hline Linas Agro & -- & 0.93 & 0.99 & 0.69 & 0.67 & 0.61 \\
\hline Agrowill & -- & -- & 0.24 & 0.85 & 0.25 & 0.84 \\
\hline Baltic Farm Land & & & & & 10.61 & 8.72 \\
\hline
\end{tabular}

For $\mathrm{X}_{4}$ ratio, market value of equity is calculated by multiplying total number of shares outstanding by market price per share. It is the opposite of debt-equity ratio.

Linas Agro has fluctuations in the ratio due to changes in debt (increase in total liabilities in year 2013 and 2015), while market value of the stock has remained constant.

Agrowill's fluctuations have been caused by different factors. In 2013, ratio has increased due to decrease in total labilities, in 2014 company has issued additional shares $(+121 \%)$ and has increased its liabilities $(+235 \%)$ while in 2015 companies share value has increased (from $0.19 \mathrm{EUR} / \mathrm{share}$ in 2014 to $0.29 \mathrm{EUR} / \mathrm{share}$ in 2015).

Baltic Farm Land's ratio has dropped due to increase in liabilities.

Table 6. $X_{5}=$ Sales/Total assets scores for agricultural companies

\begin{tabular}{|l|c|c|c|c|c|c|}
\hline \multirow{2}{*}{ Company, $X_{5}$} & \multicolumn{7}{|c|}{ Years } \\
\cline { 2 - 7 } & 2010 & 2011 & 2012 & 2013 & 2014 & 2015 \\
\hline Linas Agro & 4.10 & 3.99 & 5.36 & 3.68 & 3.66 & 3.62 \\
\hline Agrowill & 0.22 & 0.35 & 0.50 & 0.48 & 0.63 & 0.71 \\
\hline Baltic Farm Land & & & & & 0.26 & 0.42 \\
\hline
\end{tabular}

$\mathrm{X}_{5}$ ratio measures utilization of assets to generate sales of the company. It varies significantly from industry to industry; but within same industry can be show how well management is able to deal with competitive conditions.

Linas Agro still has the highest ratio of all firms, but again with a negative trend. While Agrowill's is ratio is lower, but with a positive tendency. It should be noted that Baltic Farm Land only leases land to farmers, thus its sales structure is different from Linas Agro and Agrowill and not really comparable. 
Even though Z-score provides correct placement of the companies into risk zones, more detailed analysis of the performance is required to understand the situation.

It could be useful to evaluate the scores in view of agricultural risks, such as agricultural production and other commodity price volatility risk. Agricultural products and other commodity prices are historically characterized by large fluctuations, which affect agricultural land prices. The main factor affecting profitability of agricultural business is the price of the crop, but fuel, labor, fertilizers also affect profitability level. Common agricultural risk are factors that could adversely affect agricultural sector may be weather conditions (floods, droughts, heavy rains, hail, frost, weeds, pests, diseases, fire, climate change). Any of those factors, together or separately, could have a negative impact on farmer's income and farmland values. Part of the risks can be insured, but as it has significant impact on profitability, not all Lithuanian farmers do it.

Reliance on the European Union and national subsidies is another issue specific to agricultural industry. Lithuanian and European Union farmers' activities and profits are highly dependent on the EU Common Agricultural Policy - EU and national subsidies. Recent changes in CAP are valid for the time period 2014-2020 and provide directs payments to Lithuanian farmers on average 149 EUR to 196 EUR per hectare, which constitutes $75 \%$ of EU farmer average. Subsidy policy in general, puts agribusiness in a unique position, due to specific pay-outs for the non-production related to maintaining the landscape. Research has been carried out on how government payments influence the growth and survival of farm business (Key and Roberts, 2006). It is due to the fact that farmers which operate the same amount of land, in the same country, could receive different levels of government support due to variety in crops or different amounts of land enrolled in government programs. However, for this specific analysis point of view, such differences could be treated as quality indicator of firm's management, if they are able to identify more profitable/higher-pay-out per hectare offering crops. Therefore, for this research, subsidies are treated as regular income of the business, as all three firms are eligible to same pay-outs depending on the usage of land.

All these factors would help to understand the trends of company performance better, but does not decrease the validity of current classification, as all companies are in the same industry and country, thus are subject to the same risks and conditions.

\section{Conclusion}

The purpose of this paper was to apply Altman's Z-score model on the traded Lithuanian agricultural holdings. Preliminary results show that the model correctly identified Linas Agro group as a financially stable company with Z-score above 4.4 in all years of observation. Agrowill was correctly placed into distress-zone area with Z-score below 1.2 till year 2013, while the company was undergoing restructuring due to financial difficulties. As results of restructuring became evident, and company's situation has improved, it has been reflected in improved Z-score of 1.23 and 1.58 for years 2014 and 2015, placing it in grey zone.

Baltic Farm Land has been listed in 2014 only, and is placed in safe zone with Z-score of 8.26 in 2014 and 6.56 in 2015.

Therefore, it could be said that study shows that Z Score model is a practical tool and can be used in assessing the risk of insolvency in agricultural companies, as well as risk management actions of management.

The study has several limitations that provide avenue for potential future research. This study consists of only three companies, due to limited number of traded agricultural firms. Further 
research, using adjusted Altman's Z-score should be done on privately owned agricultural companies, before any conclusion about usefulness of the model can be drawn.

At the same time, it should be noted that analysis of fluctuations in Z-score and its components provide an area for future research. Therefore, continuing this study, the author plans to extend information from Z-scores with data of Financial Statement Analysis (financial leverage, profitability, liquidity and productivity growth) in order to gain more insights into determinants of success and failure in agribusiness in Lithuania.

\section{References}

Agarwal, V., Taffler, R. (2005). Twenty-five years of z-scores in the UK: do they really work, Working paper.

Agarwal, V. and Taffler, R. (2006). Comparing the performance of market-based and accounting based bankruptcy prediction models, Working paper.

Agricultural Situation and Perspectives in the Central and Eastern European Countries. Internet. http://ec.europa.eu/agriculture/ (10.09.2016).

Altman E. (1968) Financial ratios, Discriminant analysis and the prediction of corporate bankruptcy. The Journal of Finance, vol. XIII, no. 4, pp. 589-609.

Altman, E., Hotchkiss, E. (2006). Corporate Financial Distress and Bankruptcy: Predict and Avoid Bankruptcy, Analyse and Invest in Distressed Debt, $3^{\text {rd }}$ ed. US: John Willey and Sons.

Altman, E., Iwanich-Drozdowska, M., Laitinen, E., Suvas, A. (2014). Distressed Firm and Bankruptcy Prediction in an International Context: A Review and Empirical Analysis of Altman's Z-Score Model.

Available at SSRN: http://ssrn.com/absract=2536340.

Altman, E., Narayan, P. (1997). Business Failure Classification Models: An International Survey. Financial Markets, Institutions \& Instruments, pp. 1-57.

Beaver W. (1966). Financial ratios as predictors of failure, Journal of Accounting Research, vol. 4. Empirical research in accounting: Selected studies, pp. 71-111.

Burja, C., Burja V. (2013). Entrepreneurial Risk and Performance: Empirical Evidence of Romanian Agricultural Holdings. Annales Universitatis Apulensis Series Oeconomica, no. 15 (2), pp. 561-569.

Burksaitiene, D., Mazintiene, A. (2011). The Role of Bankruptcy Forecasting in the Company Management. Economics and Management, no. 16, pp. 137-143.

Cressy, R. (2006). Why Do Most Firms Die Young? Small Business Economics, no. 26, pp. $103-116$

Cybinski, P. (2003). Doomed Firms: An Econometric Analysis of the Path to Failure. Aldershot: Ashgate Publishing.

Dietrich, J., Arcelus, F., Srinivasan, G. (2005). Predicting Financial Failure: Some Evidence from New Brunswick Agricultural Co-Ops. Annals of Public and Cooperative Economics, no. 76:2, pp. 179-194.

Dimitras, A., Zanakis, S., Zopoudinis, C. (1996). A Survey of business failures with an emphasis on failure prediction methods and industrial applications. European Journal of Operational Research, vol. 90, pp. 487-513. 
Grice, J. S., Ingram, R. W. (2001). Tests of the Generalizability of Altman's Bankruptcy Prediction Model. Journal of Business Research, no. 54, pp. 53-61.

Hampel, D., Vavrina, J., Janova, J. (2012). Predicting bankruptcy of companies based on the production function parameters. Proceedings of $30^{\text {th }}$ International Conference Mathematical Methods in Economics, Karvina, Czech Republic, 11-12 September, 2012.

Hol, S. (2006). The influence of the business cycle on bankruptcy probability. Statistics Norway Research Department, Discussion paper no. 466.

Jakovcevic, K., Andrasic, J. (2012). Diagnosis of operating business of agricultural companies in the Republic of Serbia. African Journal of Business Management, vol. 6, no. 38, pp. 10253-10259.

Karas, M., Reznakova, M. (2013). Predicting bankruptcy under alternative conditions: the effect of a change in industry and time period on the accuracy of the model. Procedia - Social and Behavioural Sciences, no. 213, pp. 397-403.

Katchova, A. L., Enlow, S. J. (2013). Financial Performance of Publicly Traded Agribusiness. Agricultural Finance Review, no. 73 (2013), pp. 58-73.

Kaylen, M., Devino, G., Procter, M. (1988). Optimal Use of Qualitative Models: An Application to Country Grain Elevator Bankruptcies. Southern Journal of Agricultural Economics, no. 20, pp. 119-126.

Key, N., Roberts, M. J. (2006). Government Payments and Farm Business Survival. American Journal of Agricultural Economics, no. 88 (2), pp. 382-392.

Kopta, D. (2009). Possibilities of financial health indicators used for prediction of future development of agricultural enterprises. Agricultural Economics, vol. 55, no. 3, pp. 111-125.

Levins, J. W. (1997). The Effect of Smaller Firms Size and Change in Firm Size on Altman's Revised Bankruptcy Prediction Model. Ph. D thesis, Nova Southeastern University. Available from: ProQuest (16 September 2014).

Lukason, O. (2014). Why and How Agricultural Firms Fail: Evidence from Estonia, Bulgarian Journal of Agricultural Science, 20 (No 1), pp. 5-11.

Madrid-Guijarro, A., Garcia-Perez-de-Lema, D., van Auken, H. (2011). An Analysis of nonfinancial factors associated with financial distress. Entrepreneurship and Regional Development, vol.23, no. 3-4, pp. 159-186.

Morris, R. (1998). Early Warning Indicators of Corporate Failure: A Critical review of Previous Research and Future Empirical Evidence, Aldershot: Ashgate Publishing.

Novotna, M., Svoboda, J. (2010). Application of a System of Indices to an Analysis of Agricultural Holding Economy in the LFA Regions, ACTA Universitatis Agriculturae et Silviculturae Mendelianae Brunensis, vol. LVIII, no. 17, pp. 165-174.

Popescu, A. (2014). Research Regarding the Use of Discriminant Analysis for Assessing the Bankruptcy Risk of Agricultural Companies, Scientific Papers Series Management, vol. 14, no. 4, pp. 193-200.

Purves, N., Niblock, S. J., Sloan K. (2015). On the relationship between financial and nonfinancial factors. Agricultural Finance Review, vol. 75 (2), pp. 282-300.

Robelo, P. C. J. (2012). Why do credit cooperatives disappear? Agricultural Finance Review, vol. 72 , no. 3, pp. 341-361. 
Roberts, M., Key, N. (2008). Agricultural Payments and Land Concentration: A Semiparametric Spatial Regression Analysis. American Journal of Agricultural Economics, no. 90 (3), pp. 627-643.

Shepard, L., Collins, R. (1982). Why Do Farmers Fail? Farm Bankruptcies 1910-78. American Journal of Agricultural Economics, no. 64 (4), pp. 609-615.

Shisia, et. al. (2014). An Analysis of the Altman's Failure Prediction Model on Corporate Financial Distress in Uchumi Supermarket in Kenya. European Journal of Business and Management, vol. 6, no. 23, pp. 27-41.

Slavickiene, A., Savieckiene, J. (2014). Comparative Analysis of Farm Economic Viability Assessment Methodologies. European Scientific Journal, vol. 10, no. 7, pp. 130-150.

Stulpiniene, V. (2011). The Concept, Causes and Measurement of Farm Financial Distress, Rural Development 2011, Conference material, pp. 249-253.

Van Auken, H., Carter, R. (2006). Small Firm Bankruptcy. Journal of Small Business Management, vol. 44 (4), pp. 493-512.

Vavrina, J., Hampel, D., Janova, J. (2013). New Approaches for the Financial Distress Classification in Agribusiness. ACTA Universitatis Agriculturae et Silviculturae Mendelianae Brunensis, vol. LXI, no. 131, pp. 1177-1182.

Warner, J. B. (1977). Bankruptcy Costs: Some Evidence. Journal of Finance, pp. 337-347.

Zhengei, G., Lansink, A. O. (2006). The Source of Productivity Growth in Dutch Agriculture: A Perspective from Finance. American Journal of Agricultural Economics, no. 88 (3), pp. 644-656. 